Article

\title{
Study on Sensitivity Differences of Critical Spontaneous Ignition Temperature between Alcohol and Hydrocarbon Fuels Based on Reaction Pathway
}

\author{
Qiang Liu ${ }^{1,2}$, Zhongchang Liu ${ }^{1}$, Xiaoming Ren ${ }^{1, *}$, Yongqiang Han ${ }^{1}$, Jun Wang ${ }^{2}$ and Jian Fang ${ }^{2}$ \\ 1 State Key Laboratory of Automotive Simulation and Control, Jilin University, Changchun 130025, China; \\ liuqiang@jlenu.edu.cn (Q.L.); liuzc@jlu.edu.cn (Z.L.); hanyq@jlu.edu.cn (Y.H.) \\ 2 Research Center of Automobile Safety Technology of Jilin Engineering Normal University, \\ Innovative Research Team of Jilin Engineering Normal University (IRTJLENU), Jilin Engineering Normal \\ University, Changchun 130052, China; wangjun0620@163.com (J.W.); lq200379@tom.com (J.F.) \\ * Correspondence: ren930912@163.com; Tel.: +86-188-4318-8462
}

Received: 25 November 2018; Accepted: 9 January 2019; Published: 1 February 2019

\begin{abstract}
In this article, the critical spontaneous ignition temperature of both hydrocarbon and alcohol fuel was acquired on a constant volume combustion bomb platform by slowly heating the inner charges, and then followed by using the CHEMKIN-PRO software to simulate the auto-ignition-dominated characteristic and parameter sensitivity of the two kinds of fuels. Results revealed that in different conditions, the critical spontaneous ignition temperature of methanol changed dramatically, with a maximum temperature of $50 \mathrm{~K}$, while the counterpart temperature of n-heptane remained an invariable value of $553 \mathrm{~K}$ within a large changeable scope of temperature, and only a maximum temperature of $10 \mathrm{~K}$ was observed. The maximum difference of spontaneous ignition temperature between methanol and $\mathrm{n}$-heptane reached $270 \mathrm{~K}$. At the same time, a minimum difference of $170 \mathrm{~K}$ was obtained as well. The complete reaction of methanol requires 5 steps, involving 6 components and 11 elementary reactions. However, for the comparative part-n-heptane, more than 20 main self-ignition reactions were involved, which indicated that the whole reaction process of n-heptane has more reaction pathway branches and it was much more complicated compared to methanol. The differences of the reaction pathways triggered a considerable distinction of critical self-ignition temperature between the two charges, making a "step-by-step" spontaneous ignition combustion mode possible. In this way, a further high-efficient and clean combustion can be available to cater to much more stringent emission regulations in the future.
\end{abstract}

Keywords: reaction pathway; influence parameter; critical spontaneous ignition temperature; automotive diesel engine

\section{Introduction}

The widespread use of internal combustion engines has brought a lot of convenience to our lives but also caused tremendous pressure on energy and the environment. The consumption of fossil energy has caused serious pollution to the environment, and the shortage of nonrenewable resources has also brought about a huge crisis. Energy saving and emission reduction have become the main direction of internal combustion engine research. Given the highly-developed pursuit of energy conservation and emission reduction worldwide [1], a new combustion mode with high efficiency and cleanness based on reaction-controlled homogeneous gas mixture cascade combustion has been put forward by our study group. In this mode, the combustion process of several pure fuels, among which the cetane number/spontaneous combustion performance differs vastly, are dominated by the self-combustion/compression combustion characteristic and chemical atmosphere [2]. Differences 
in the spontaneous ignition performance make a step-by-step combustion realizable. The "critical spontaneous ignition boundary" is used to stabilize the combustion, and the "step-by-step" exothermic characteristic is used to control the rough degree of combustion and the load expansion simultaneously. The critical element ensuring a "step-by-step" spontaneous ignition lies in that the spontaneous ignition boundary of the fuels has an adequate threshold value, i.e., in the circumstance where the forestage combustion cannot reach the self-ignition point of its composition, some extra energy (compression or heating) should be added. In this paper, through the study of the combustion boundary conditions of hydrocarbon fuel and alcohol fuel with large cetane number difference along with the analysis of subsequent reaction path, it is concluded that the difference in the spontaneous ignition temperature between hydrocarbon fuel and alcohol fuel is quite large, and the reason for this phenomenon was explained from the perspective of the reaction mechanism using CHEMKIN software (4.1, Reaction Design, San Diego, CA, USA).

In-depth study of the formation, transformation, and extinction of key harmful substances in the fuel combustion process under different boundary combinations and clarification of the sensitive boundaries of various harmful substances provide an important reference for the selection of strategies and methods for the realization of cascade spontaneous combustion and accurately use the thermochemical atmosphere in the cylinder. To achieve cascade combustion, we must first study the self-ignition/step spontaneous ignition specificity of the reaction control homogeneous mixture; that is, from the perspective of the chemical reaction kinetics of fuel, the reaction history of fuel is studied.

There have been many studies on the chemical reaction kinetics of fuel combustion in recent years. Jilin University studied the mechanism of the methanol combustion process in detail and introduced the molecular collision theory, ignition mechanism, and thermal spontaneous combustion theory in chemical reaction kinetics. Fieweger et al. [3] studied the self-ignition characteristics of several fuels, including stoichiometric methanol/air mixtures at pressures of 13 and 40 bar and temperatures of approximately 800-1200 K. Ultan Burke et al. [4] measured new ignition delay times for methanol in a shock tube (ST) and a rapid compression machine (RCM). The newly measured experimental data were used to develop a new, detailed chemical kinetic model. Noorani et al. [5] studied the high temperature ignition of $C_{1}-C_{4}$ primary alcohols, methanol, ethanol, n-propanol, and n-butanol at 2, 10, and 1212 $\mathrm{kPa}$. The ignition delay times of methanol are comparable with those of the other alcohols but show a slightly lower activation energy than the other fuels. V. Aranda et al. [6] studied a detailed chemical kinetic model for oxidation of $\mathrm{CH} 3 \mathrm{OH}$ at high pressure and intermediate temperatures were developed and validated experimentally. J.M. Smith et al. [7] studied ignition delay times for the oxidation of four isomers-n-heptane, 2,2-dimethylpentane, 2,3-dimethylpentane, and 2,2,3-trimethylbutane-under stoichiometric conditions at a reflected shock pressure of $202 \mathrm{kPa}$. Shucheng $\mathrm{Xu}$ et al. [8] investigated kinetics and mechanisms for reactions of $\mathrm{OH}$ with methanol and ethanol at the CCSD (Coupled Cluster with Singles and Doubles) (T)/6-311 + G(3df, 2p)/ /MP2/6-311 + G(3df, 2p) level of theory. $X$. Lu et al. [9] studied ignition timing in the homogeneous charge compression ignition (HCCI) of n-heptane by port injection of reaction inhibitors and obtained chemical mechanistic information relevant to the ignition behavior. In this paper, we focus on the chemical reaction mechanism of methanol and n-heptane in CHEMKIN and find the cause of the macroscopic spontaneous ignition temperature difference and provide a theoretical basis for the possibility of achieving the cascade spontaneous combustion mode.

\section{Experimental Methods and Results}

The alcohol and hydrocarbon fuels were slowly heated to spontaneous ignition on a constant-volume combustion bomb experimental platform. Taking the steep change of pressure as the main criterion and using the temperature rise as the reference criterion, the critical spontaneous ignition temperature of various fuels under different boundary combinations was determined. There are three experimental methods for each test fuel: Air constant, fuel constant and stoichiometric ratio. The experimental platform is shown in Figure 1 [10]. The main instruments and equipment of the 
experiment are shown in Table 1. Here, we take methanol as an example and the specific parameters are shown in Tables 1-4.

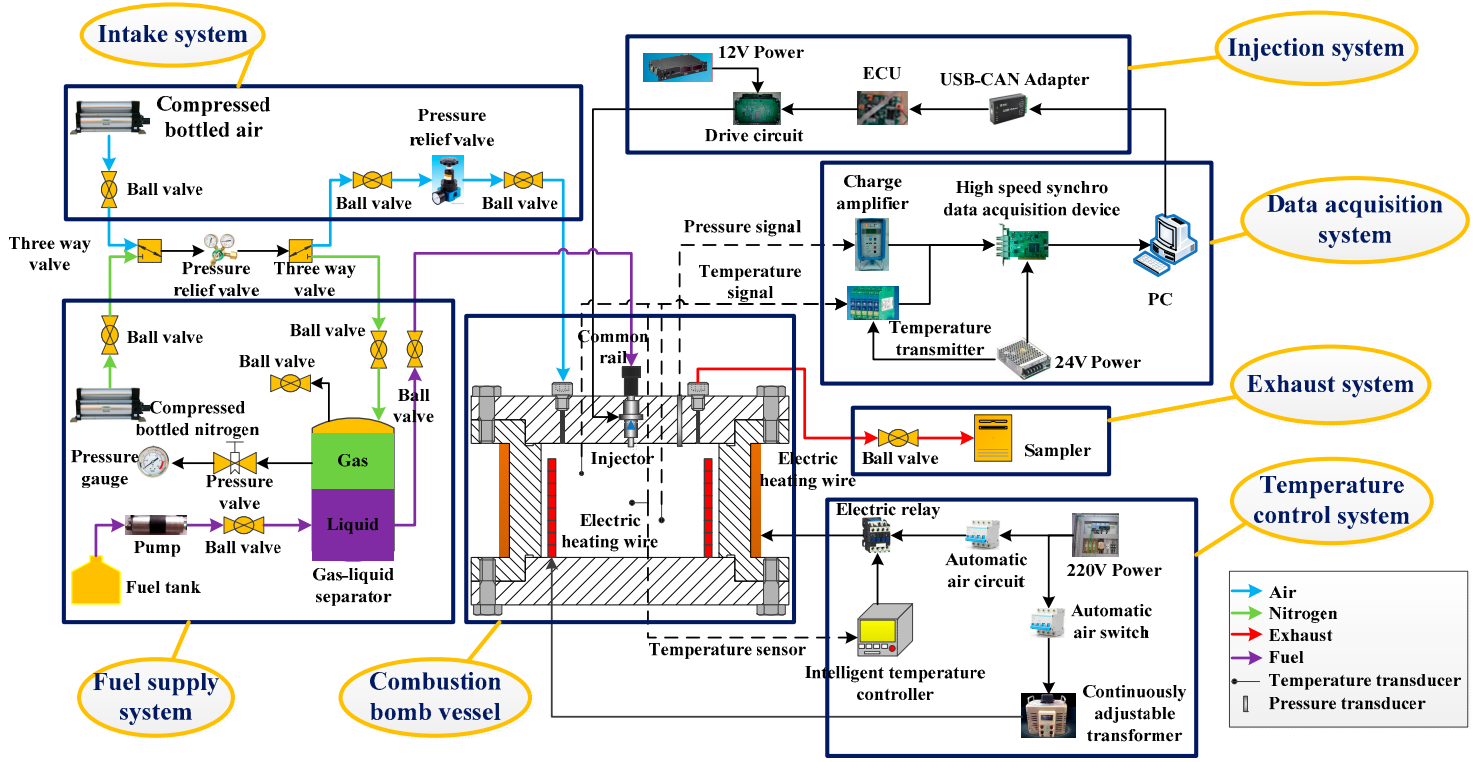

Figure 1. Constant volume bomb system.

Table 1. The main equipment of the experiment.

\begin{tabular}{ccc}
\hline Apparatus & Manufacturer & Type \\
\hline Temperature transducer & MingYang (Tianjin, China ) & WRNK-191 \\
Pressure transducer & Kistler (Winterthur, Switzerland) & KISTLER6125B \\
Temperature transmitter & PARAGON (Forestville, CA, USA) & PA-15-4-1 (K) \\
Charge amplifier & Kistler (Winterthur, Switzerland) & 5051A \\
Electrical control unit & Freescale (Austin, TX, USA) & MC9S12XEP100MAL \\
USB & DAM-C3110 (Beijing, China) & USB-CAN \\
Multi-function data USB & HengRuiFeng (Suzhou, China) & USB2.0 \\
\hline
\end{tabular}

Table 2. Methanol equivalent ratio test data.

\begin{tabular}{cccccc}
\hline $\begin{array}{c}\text { Intake } \\
\text { Pressure (psi) }\end{array}$ & $\begin{array}{c}\text { Intake } \\
\text { Pressure (kPa) }\end{array}$ & $\begin{array}{c}\text { Temperature } \\
\mathbf{( K )}\end{array}$ & $\begin{array}{c}\text { Air Amount } \\
\mathbf{( m o l )}\end{array}$ & $\begin{array}{c}\text { Equivalent } \\
\text { Ratio }\end{array}$ & Fuel (mol) \\
\hline 240 & 1655 & 473 & 0.427 & 1 & 0.0596 \\
220 & 1517 & 473 & 0.391 & 1 & 0.0546 \\
200 & 1379 & 473 & 0.356 & 1 & 0.0497 \\
180 & 1241 & 473 & 0.320 & 1 & 0.0447 \\
160 & 1103 & 473 & 0.284 & 1 & 0.0397 \\
140 & 965 & 473 & 0.249 & 1 & 0.0348 \\
120 & 827 & 473 & 0.213 & 1 & 0.0298 \\
100 & 689 & 473 & 0.178 & 1 & 0.0248 \\
80 & 552 & 473 & 0.142 & 1 & 0.0199 \\
\hline
\end{tabular}


Table 3. Methanol air amount constant test data.

\begin{tabular}{cccccc}
\hline $\begin{array}{c}\text { Intake } \\
\text { Pressure (psi) }\end{array}$ & $\begin{array}{c}\text { Intake } \\
\text { Pressure (kPa) }\end{array}$ & $\begin{array}{c}\text { Temperature } \\
(\mathbf{K})\end{array}$ & $\begin{array}{c}\text { Air Amount } \\
\mathbf{( m o l )}\end{array}$ & $\begin{array}{c}\text { Equivalent } \\
\text { Ratio }\end{array}$ & Fuel (mol) \\
\hline 200 & 1379 & 473 & 0.356 & 2.0 & 0.0993 \\
200 & 1379 & 473 & 0.356 & 1.8 & 0.0894 \\
200 & 1379 & 473 & 0.356 & 1.6 & 0.0795 \\
200 & 1379 & 473 & 0.356 & 1.4 & 0.0695 \\
200 & 1379 & 473 & 0.356 & 1.2 & 0.0596 \\
200 & 1379 & 473 & 0.356 & 1.0 & 0.0497 \\
200 & 1379 & 473 & 0.356 & 0.8 & 0.0397 \\
200 & 1379 & 473 & 0.356 & 0.6 & 0.0298 \\
200 & 1379 & 473 & 0.356 & 0.4 & 0.0199 \\
\hline
\end{tabular}

Table 4. Methanol constant fuel test data.

\begin{tabular}{cccccc}
\hline $\begin{array}{c}\text { Intake } \\
\text { Pressure (psi) }\end{array}$ & $\begin{array}{c}\text { Intake } \\
\text { Pressure } \mathbf{( k P a )}\end{array}$ & $\begin{array}{c}\text { Temperature } \\
\mathbf{( K )}\end{array}$ & $\begin{array}{c}\text { Air Amount } \\
\mathbf{( m o l )}\end{array}$ & $\begin{array}{c}\text { Equivalent } \\
\text { Ratio }\end{array}$ & Fuel (mol) \\
\hline 100.00 & 689.48 & 473 & 0.178 & 2.0 & 0.0497 \\
111.1 .1 & 766.08 & 473 & 0.198 & 1.8 & 0.0497 \\
125.00 & 861.84 & 473 & 0.222 & 1.6 & 0.0497 \\
142.86 & 984.97 & 473 & 0.254 & 1.4 & 0.0497 \\
166.67 & 1149.13 & 473 & 0.296 & 1.2 & 0.0497 \\
200.00 & 1378.95 & 473 & 0.356 & 1.0 & 0.0497 \\
250 & 1723.69 & 473 & 0.444 & 0.8 & 0.0497 \\
333.33 & 2298.25 & 473 & 0.593 & 0.6 & 0.0497 \\
500.00 & 3447.38 & 473 & 0.889 & 0.4 & 0.0497 \\
\hline
\end{tabular}

The relationship between the critical spontaneous ignition temperature and equivalence ratio of fuel under a constant amount of fuel as well as air volume and the relationship between critical spontaneous ignition temperature and inlet pressure of several fuels at stoichiometric ratio are shown in Figures 2 and 3.

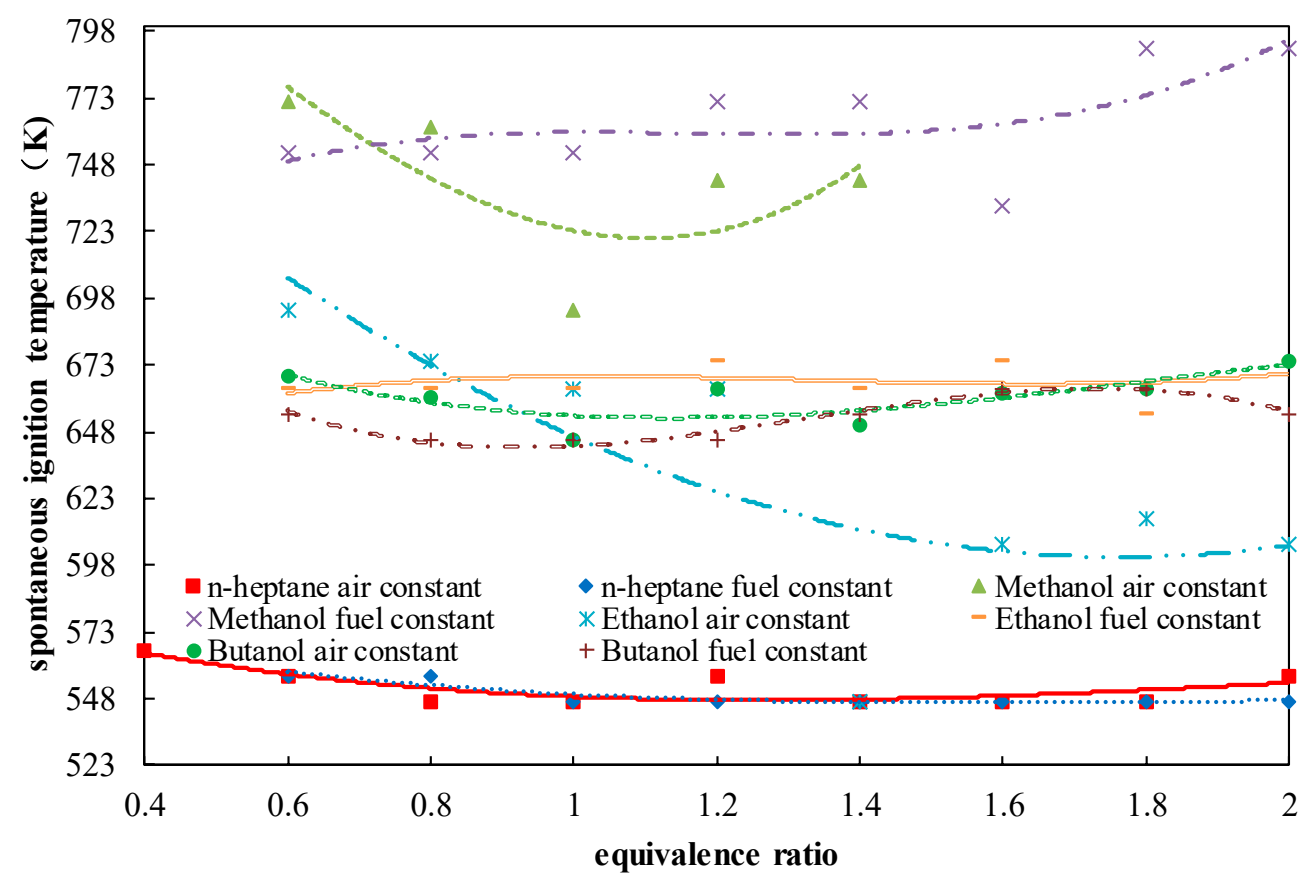

Figure 2. The relationship between equivalence ratio and spontaneous ignition temperature at $1379 \mathrm{kPa}$, $473 \mathrm{~K}$. 


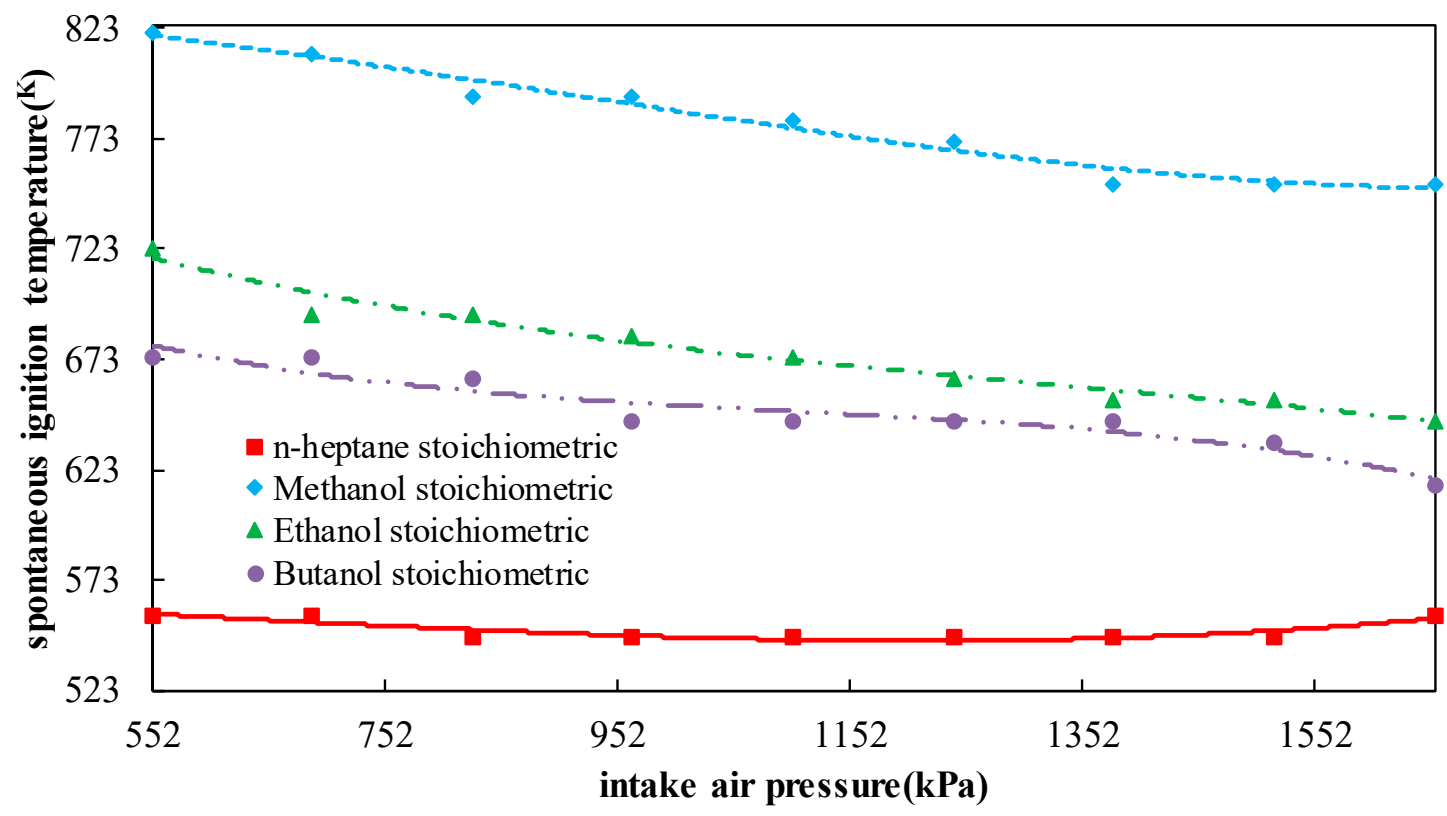

Figure 3. The relationship between intake air pressure and spontaneous ignition temperature at $473 \mathrm{~K}$, stoichiometric ratio.

According to Figures 2 and 3, in the same equivalence ratio, the spontaneous ignition temperature of alcohol fuel changed rapidly, with a maximum variation of $50 \mathrm{~K}$ under a constant amount of air and fuel in the condition of $1379 \mathrm{kPa}$ and $473 \mathrm{~K}$. The spontaneous ignition temperature of Hydrocarbon fuel remained an invariable value of $553 \mathrm{~K}$ within a large changeable scope of temperature, and only a maximum temperature of $10 \mathrm{~K}$ was observed. The difference of the spontaneous ignition temperature between methanol and n-heptane can reach $270 \mathrm{~K}$. The spontaneous ignition temperature of alcohol fuels is more sensitive to the change of external conditions than that of hydrocarbon fuels.

In order to explain the difference between the spontaneous ignition temperature of alcohol fuel and hydrocarbon fuel and their sensitivity to the change of external conditions, the chemical reaction mechanism is inferred as follows [11,12].

Fuel combustion is composed of a series of chemical reactions. The combustion of alcohol fuels always has some specific reactions, which are called leading reactions, and the reaction path of alcohol fuels is relatively single. When the external condition of equivalent ratio or inlet pressure is changed, there will be a great influence on the critical spontaneous combustion temperature of fuel [13].

Hydrocarbon fuel reactions are more complex [14]. The reaction is carried out by many major reactions. When the external conditions change, the internal main reactions rise and fall. There is always a new major reaction to promote ignition or to suppress ignition [15], so the spontaneous ignition temperature of hydrocarbon fuels shows insensitive characteristics to the outside.

\section{Establishment of Simulation Model and Selection of Mechanism}

From the experiment results, we can see the great difference of spontaneous combustion temperature between alcohol fuel and hydrocarbon fuel, especially methanol and n-heptane. This is in line with the conditions of our proposed new combustion mode, one of which is that the cetane number/spontaneous combustion performance differs vastly, and our group want to study the possibility of methanol and n-heptane co-combustion. Thus, we chose methanol and n-heptane to analyze the reaction mechanism so that we can get the detailed reaction and explore the possibility on the cross-coupling mechanism of critical natural boundary of n-heptane-methanol spontaneous combustion. In this paper, the detailed oxidation mechanism of n-heptane was provided by the National key Laboratory of Lawrence Livermore, including 560 components and 2827 elementary 
reactions. The mechanism of methanol was derived from Princeton University, consisting of 21 components and 90 elementary reactions. The mechanism, which has been verified by many authorities, has an excellent universality using the closed homogeneous batch reactor (4.1, Reaction Design, San Diego, CA, USA) of CHEMKIN-PRO [16], as shown in Figure 4. The chemical mechanism of the fuel chemical reaction was introduced to simulate the combustion of methanol and n-heptane in a constant volume combustion bomb. The boundary conditions involved in the simulation were consistent with the experimental conditions of the test bench. The combustion chain reaction of different fuel differs a lot; i.e., the reaction path is different. Based on the production rate of methanol and n-heptane, the main reaction characteristics of methanol and n-heptane spontaneous combustion were obtained by drawing the reaction path diagram. Firstly, the temperature and the concentration curve of important substances were plotted to discover the key substances of the mark ignition, and then the sensitivity of the substance was analyzed to further investigate the most critical reactions with large sensitivity coefficients. Meanwhile, the production rate of the substances in the reaction was analyzed to draw a reaction path diagram of the alcohols fuel and hydrocarbons fuel.

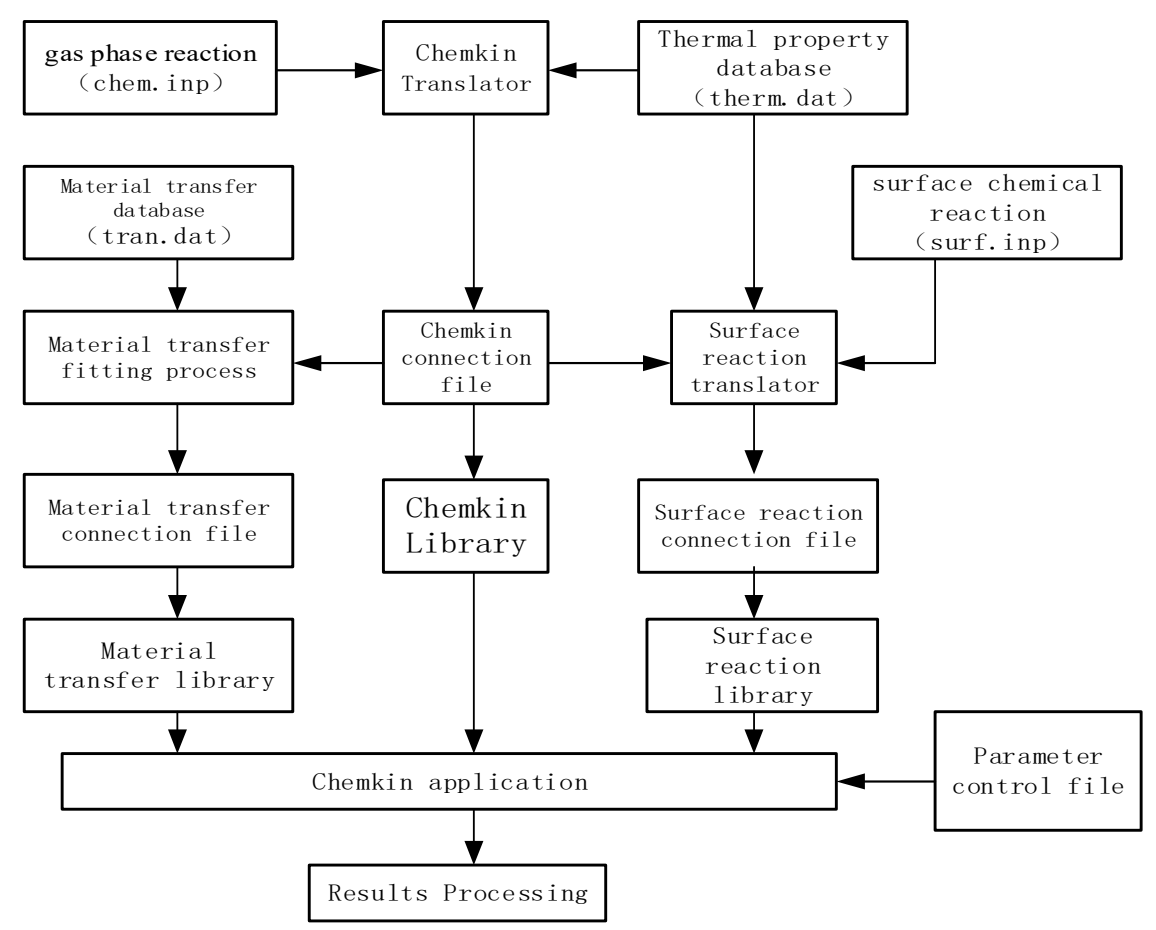

Figure 4. CHEMKIN-PRO structure diagram.

\section{Analysis of Dominant Reaction Characteristics of Methanol Spontaneous Ignition}

\subsection{Determination of Methanol Ignition Markers}

It can be seen from Figure 5 that a small amount of methanol undergoes a slow oxidation reaction before combustion occurs, and methanol is consumed in a small amount, accompanied by a small amount of $\mathrm{H}_{2} \mathrm{O}_{2}$ and $\mathrm{CH}_{2} \mathrm{O}$. After a delay of about $0.079 \mathrm{~s}$, temperature rises sharply and $\mathrm{CO}_{2}$ starts to form, and methanol is quickly consumed until the mol fraction becomes zero, accompanied by a sudden increase of the $\mathrm{OH}$ mol fraction and temperature curve. Therefore, $\mathrm{OH}$ is used as the symbolic product of alcohol fuel ignition [17]. 


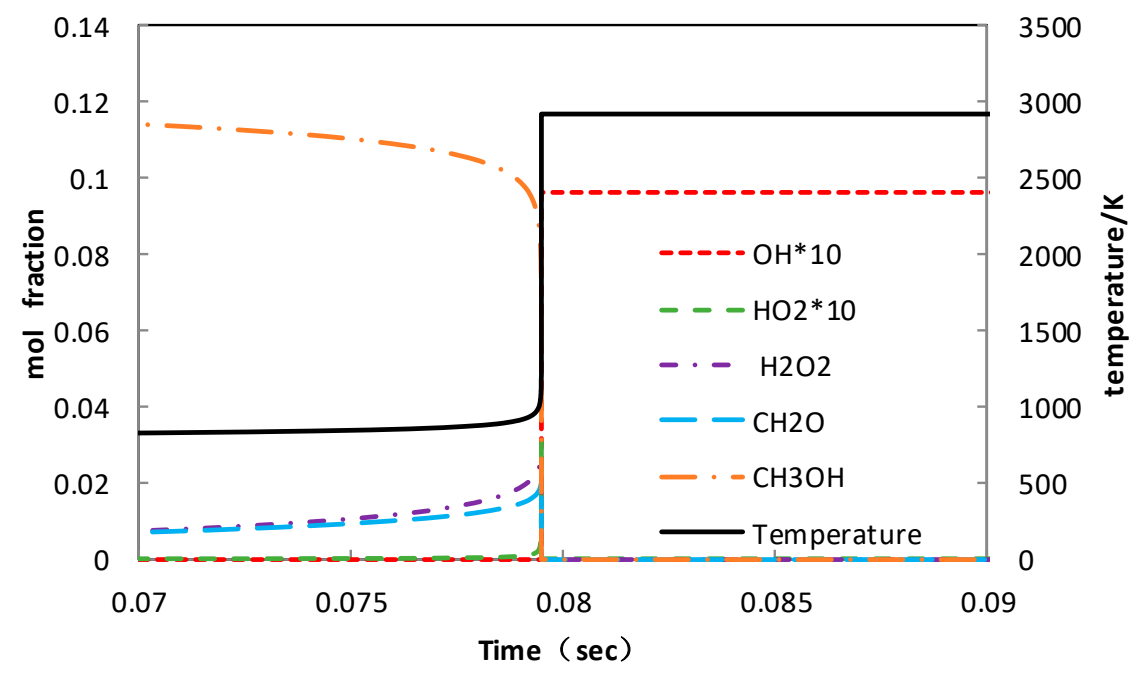

Figure 5. The mol fraction and temperature curve of methanol and its important free radicals.

\subsection{Sensitivity Analysis Based on OH Group Generation and Consumption}

Sensitivity analysis is to study the influence of the system for small disturbances under certain boundary conditions, that is, to measure the change of system characteristic quantity caused by the small change of each reaction rate constant in the chemical reaction by the magnitude of sensitivity. Through sensitivity analysis, it is very convenient and effective to find the reaction that has the greatest impact on the parameters. In order to make the comparison more convenient, the sensitivity coefficient of each reaction is standardized, that is, the sensitivity coefficient of each reaction is divided by the absolute value of the reaction sensitivity coefficient, and the normalization coefficient is obtained. The $\mathrm{OH}$ sensitivity analysis of the methanol ignition moment is shown in Figure 6.

Figure 6 shows the sensitivity analysis of $\mathrm{OH}$ group formation and consumption reaction during methanol oxidation at different temperatures, pressures, and equivalent ratios [18]. The positive sensitivity coefficient shows that the $\mathrm{OH}$ group production and the overall reaction activity increase, while the sensitivity coefficient is negative. From Figure 6, it can be found that the reactions that affect $\mathrm{OH}$ under different conditions are consistent, and the most influential ones are as follows:

$$
\begin{aligned}
& \text { R91: } \mathrm{CH}_{3} \mathrm{OH}+\mathrm{HO}_{2}=\mathrm{CH}_{2} \mathrm{OH}+\mathrm{H}_{2} \mathrm{O}_{2} \\
& \text { R89: } \mathrm{CH}_{3} \mathrm{OH}+\mathrm{O}_{2}=\mathrm{CH}_{2} \mathrm{OH}+\mathrm{HO}_{2} \\
& \text { R46: } \mathrm{CH}_{2} \mathrm{O}+\mathrm{HO}_{2}=\mathrm{HCO}+\mathrm{H}_{2} \mathrm{O}_{2} \\
& \text { R20: } \mathrm{H}_{2} \mathrm{O}_{2}(+\mathrm{M})=2 \mathrm{OH} \\
& \text { R19:2 } \mathrm{HO}_{2}=\mathrm{H}_{2} \mathrm{O}_{2}+\mathrm{O}_{2} \\
& \text { R18:2 } \mathrm{HO}_{2}=\mathrm{H}_{2} \mathrm{O}_{2}+\mathrm{O}_{2}
\end{aligned}
$$

The reaction with the highest sensitivity coefficient under each condition is R91, and its value is 1 . Although the dominant reaction types are the same at temperatures of $1000 \mathrm{~K}$ and $800 \mathrm{~K}$, the $\mathrm{OH}$ sensitivity coefficients are quite different. The hydroxyl sensitivity coefficient of R25 is 1 at a temperature of $1000 \mathrm{~K}$, but the hydroxyl sensitivity coefficient is almost 0 at $800 \mathrm{~K}$. The hydroxyl sensitivity coefficient of R20 reaction is -0.4 at $1000 \mathrm{~K}$, while the sensitivity coefficient is +0.8 at $800 \mathrm{~K}$. At $1000 \mathrm{~K}$, the sensitivity coefficient of the R18.R19 reaction is almost 0 , and the sensitivity coefficients of the R18 and R19 reactions are -0.3 and -0.2 , respectively. Changing the temperature has a greater effect on the hydroxyl sensitivity coefficient of the dominant reaction [19].

From the production rate analysis diagrams of important intermediates of methanol spontaneous ignition [20] in Figures 7 and 8, it can be seen that methanol is mainly consumed by six reactions, i.e., R84, R85, R86, R87, R88, and R91, in which $\mathrm{CH}_{2} \mathrm{OH}$ was formed by the R84, R86, R88, and R91 reactions, accounting for $71.89 \%$; that is, $71.89 \%$ of methanol combustion produced $\mathrm{CH}_{2} \mathrm{OH}$, 
and the remaining $28.11 \%$ formed $\mathrm{CH}_{3} \mathrm{O}$ by the reaction of $\mathrm{R} 85$ and $\mathrm{R} 87$. Both $\mathrm{CH}_{2} \mathrm{OH}$ and $\mathrm{CH}_{3} \mathrm{O}$ produced $\mathrm{CH}_{2} \mathrm{O}$, which shows that $\mathrm{CH}_{2} \mathrm{O}$ is an important intermediate for methanol combustion. The consumption of $\mathrm{CH}_{2} \mathrm{O}$ is mainly through the reaction of $\mathrm{R} 42$ and $\mathrm{R} 44$ to generate $\mathrm{HCO}$, so that the small molecular substances are further increased. Most of the $\mathrm{HCO}$ is converted into $\mathrm{CO}_{2}$ through reaction to form $\mathrm{CO}$ to terminate the reaction chain, and a small part directly generates $\mathrm{CO}_{2}$. The reaction was terminated.

$1000 \mathrm{k}$

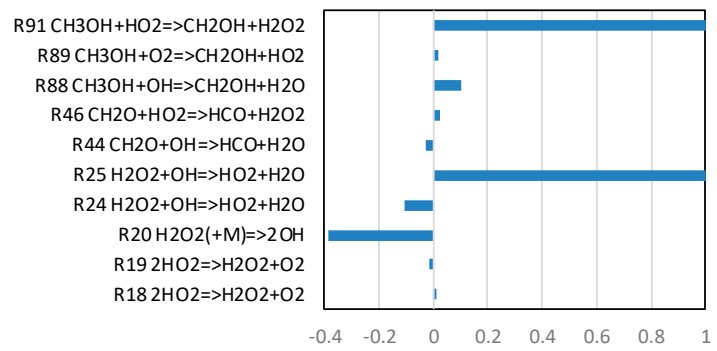

(a)

\section{$3861 \mathrm{kPa}$}

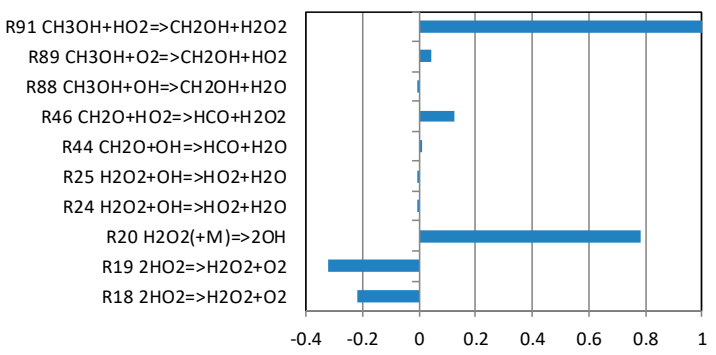

(c)

\section{Equivalent ratio 1}

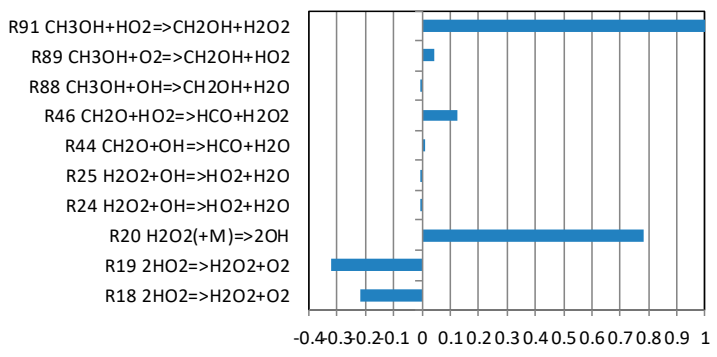

(e)
$800 \mathrm{k}$

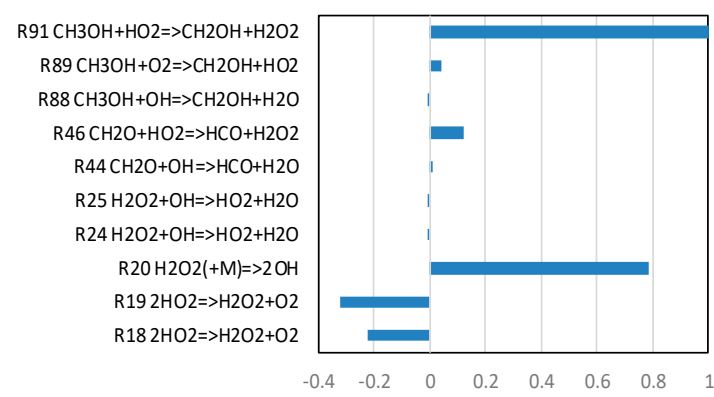

(b)

$772 \mathrm{kPa}$

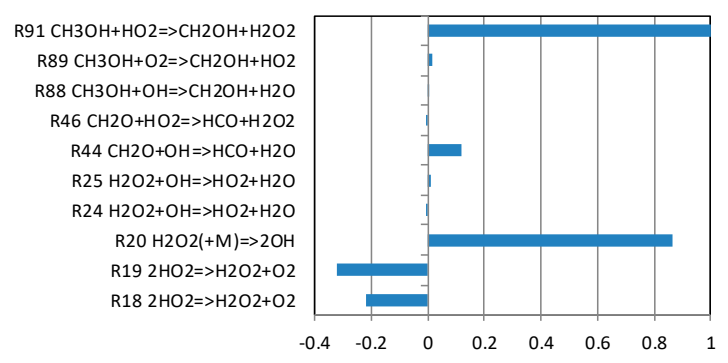

(d)

Equivalent ratio 0.2

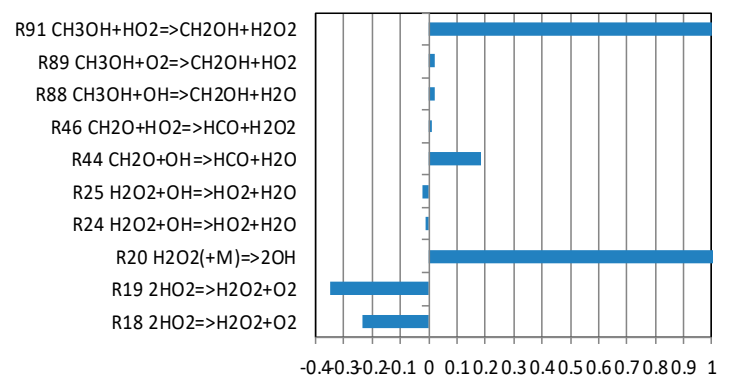

(f)

Figure 6. Reaction diagram of methanol hydroxyl sensitivity under different conditions. (a) tempature $1000 \mathrm{k}$; (b) tempature $800 \mathrm{k}$; (c) pressure: $3861 \mathrm{kPa}$; (d) pressure: $772 \mathrm{kPa}$. (e) equivalent ratio 1; (f) equivalent ratio 0.2 . 


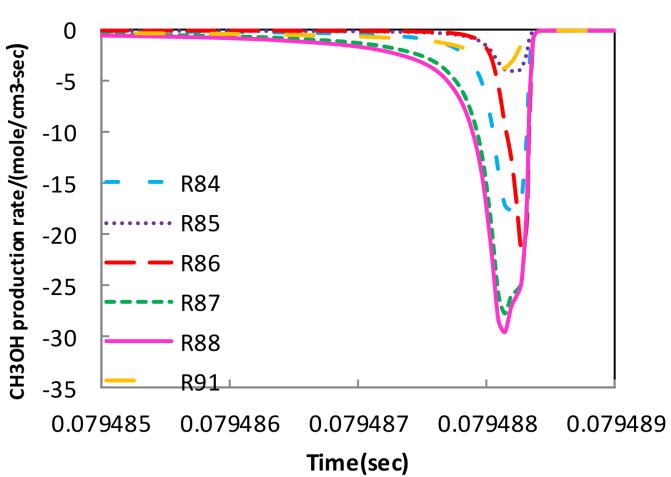

(a)

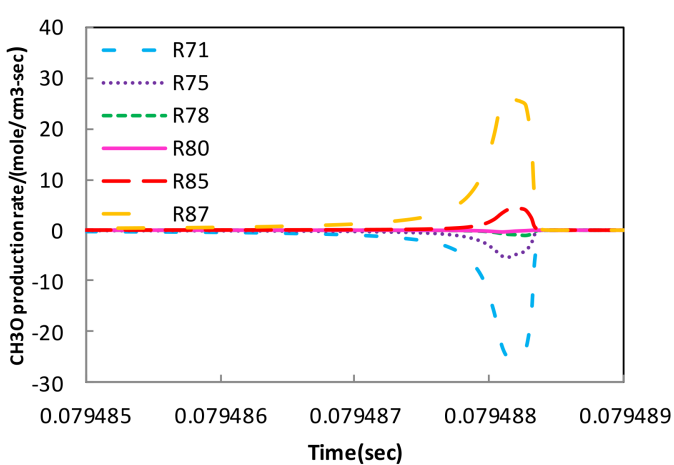

(c)

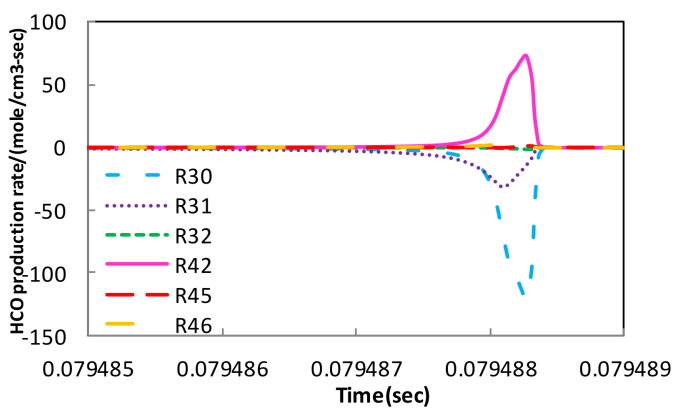

(e)

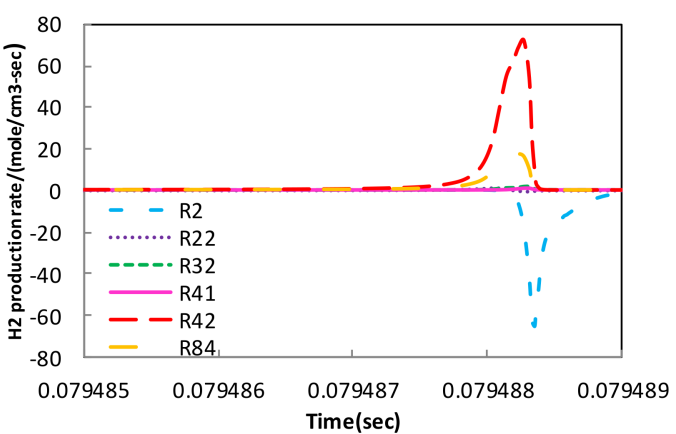

(g)

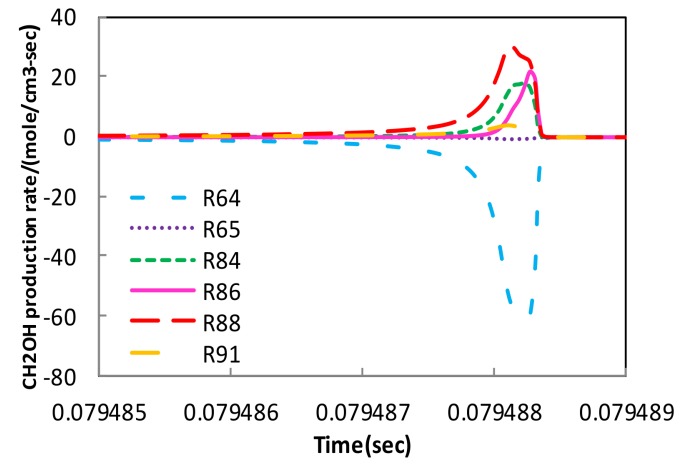

(b)

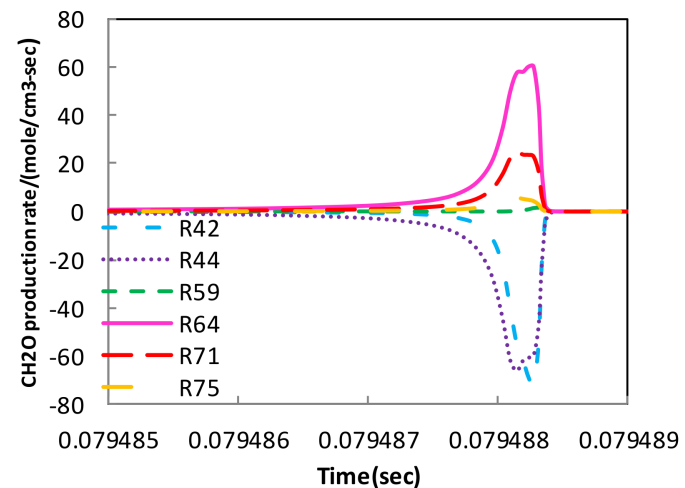

(d)

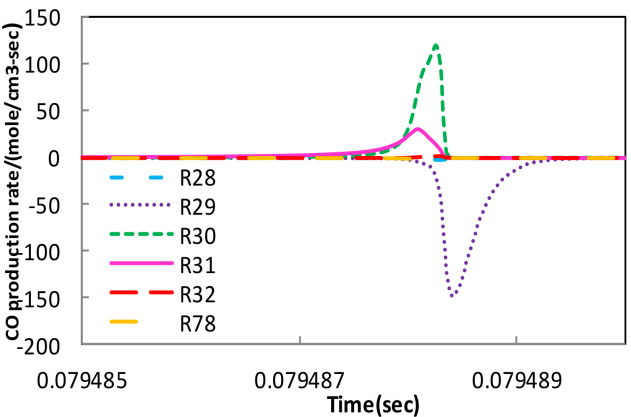

(f)

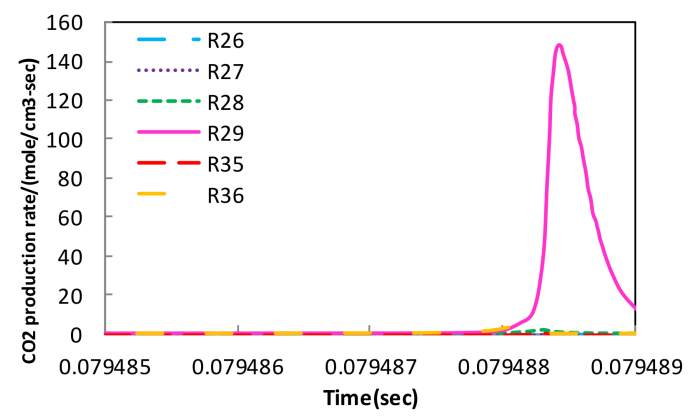

(h)

Figure 7. Production rate analysis of methanol. (a) $\mathrm{CH}_{3} \mathrm{OH}$ production rate; (b) $\mathrm{CH}_{2} \mathrm{OH}$ production rate; (c) $\mathrm{CH}_{3} \mathrm{O}$ production rate; (d) $\mathrm{CH}_{2}$ Oproduction rate; (e) $\mathrm{HCO}$ production rate; (f) $\mathrm{CO}$ production rate; (g) $\mathrm{H}_{2}$ production rate; $(\mathbf{h}) \mathrm{CO}_{2}$ production rate. 


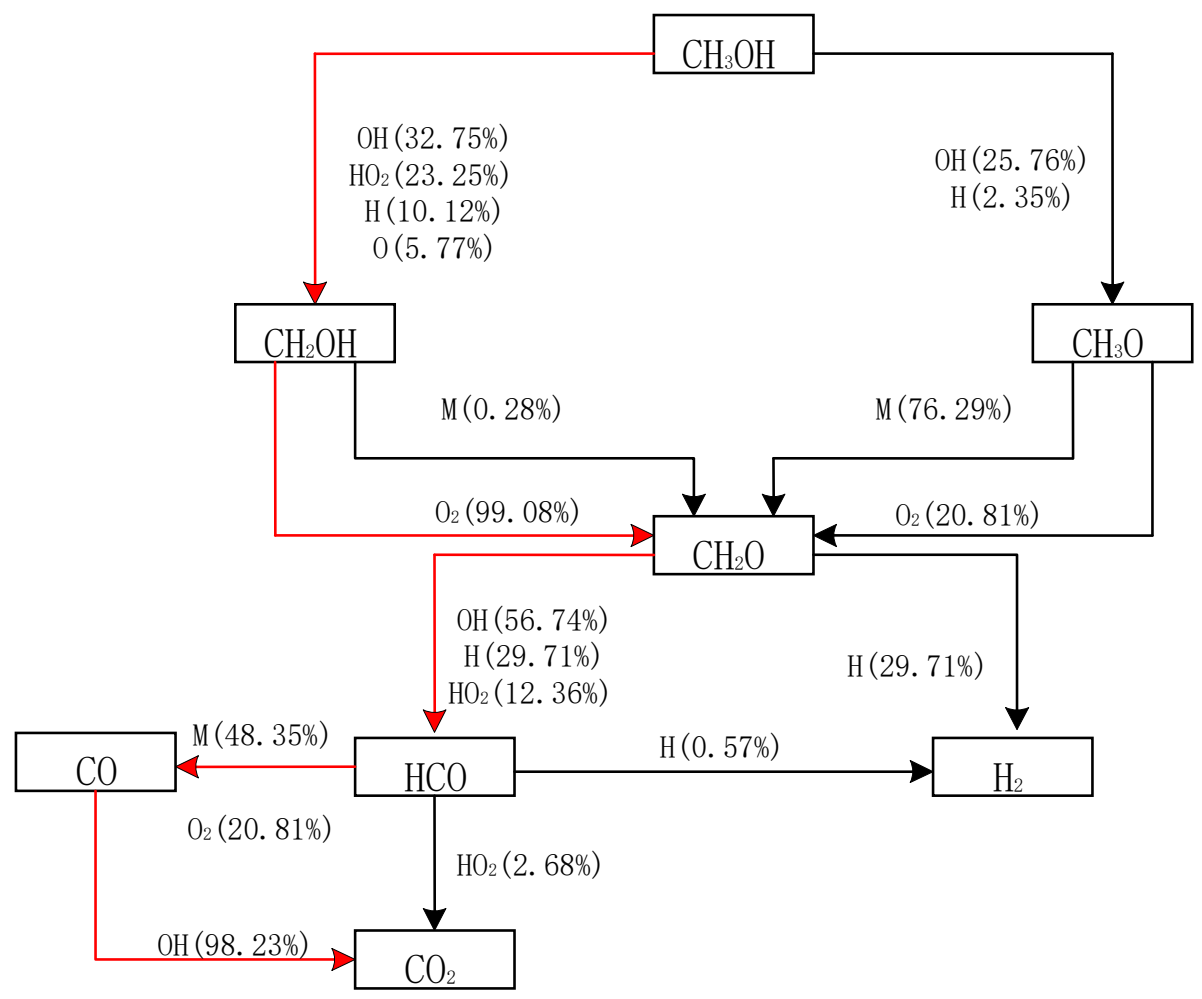

Figure 8. Reaction path diagram of methanol.

It can be obtained from Figures 6-8 that the methanol oxidation reaction process is relatively simple, the reaction path is comparatively single, and the spontaneous ignition temperature is extremely susceptible to external influence. Therefore, the change of external conditions has a great influence on the ignition of methanol. If only the external conditions are not reached by the energy barrier of the dominant reaction of methanol, the reaction will not proceed, and the subsequent reaction is difficult to carry out.

\section{Analysis of the Dominant Reaction Characteristics of N-heptane Spontaneous Combustion}

\subsection{N-Heptane Ignition Marker}

Figure 9 shows the variation of main substances, such as $\mathrm{OH}, \mathrm{HO}_{2}, \mathrm{H}_{2} \mathrm{O}_{2}, \mathrm{CH}_{2} \mathrm{O}$, and $\mathrm{NC}_{7} \mathrm{H}_{16}$, over time during the ignition process. At $983.73 \mathrm{~ms}, \mathrm{NC}_{7} \mathrm{H}_{16}$ fuel is quickly consumed, but the fuel heat release is small, and the corresponding temperature curve increases little at this time. At 983.76 $\mathrm{ms}$, the $\mathrm{NC}_{7} \mathrm{H}_{16}$ mole fraction decreases to 0 . At this time, the $\mathrm{OH}$ mole fraction and the temperature curve increase almost simultaneously, that is, $\mathrm{OH}$ consumes a lot of fuel during fuel ignition [21]. At the moment of rapid consumption of $\mathrm{NC}_{7} \mathrm{H}_{16}$, the $\mathrm{HO}_{2}$ mole fraction accumulated to the peak, and $\mathrm{HO}_{2}$ partially remained after the first consumption of $\mathrm{NC}_{7} \mathrm{H}_{16}$, and the $\mathrm{HO}_{2}$ mole fraction also fell back to 0 after the second fuel was completely consumed. Therefore, both $\mathrm{OH}$ and $\mathrm{HO}_{2}$ affect the ignition reaction of n-heptane; in particular, the concentration (molar fraction) of $\mathrm{OH}$ and the reaction rate determine the ignition reaction process of the fuel. It can be concluded that $\mathrm{OH}$ can be used as a marker for the ignition of paraffin fuels [22]. 


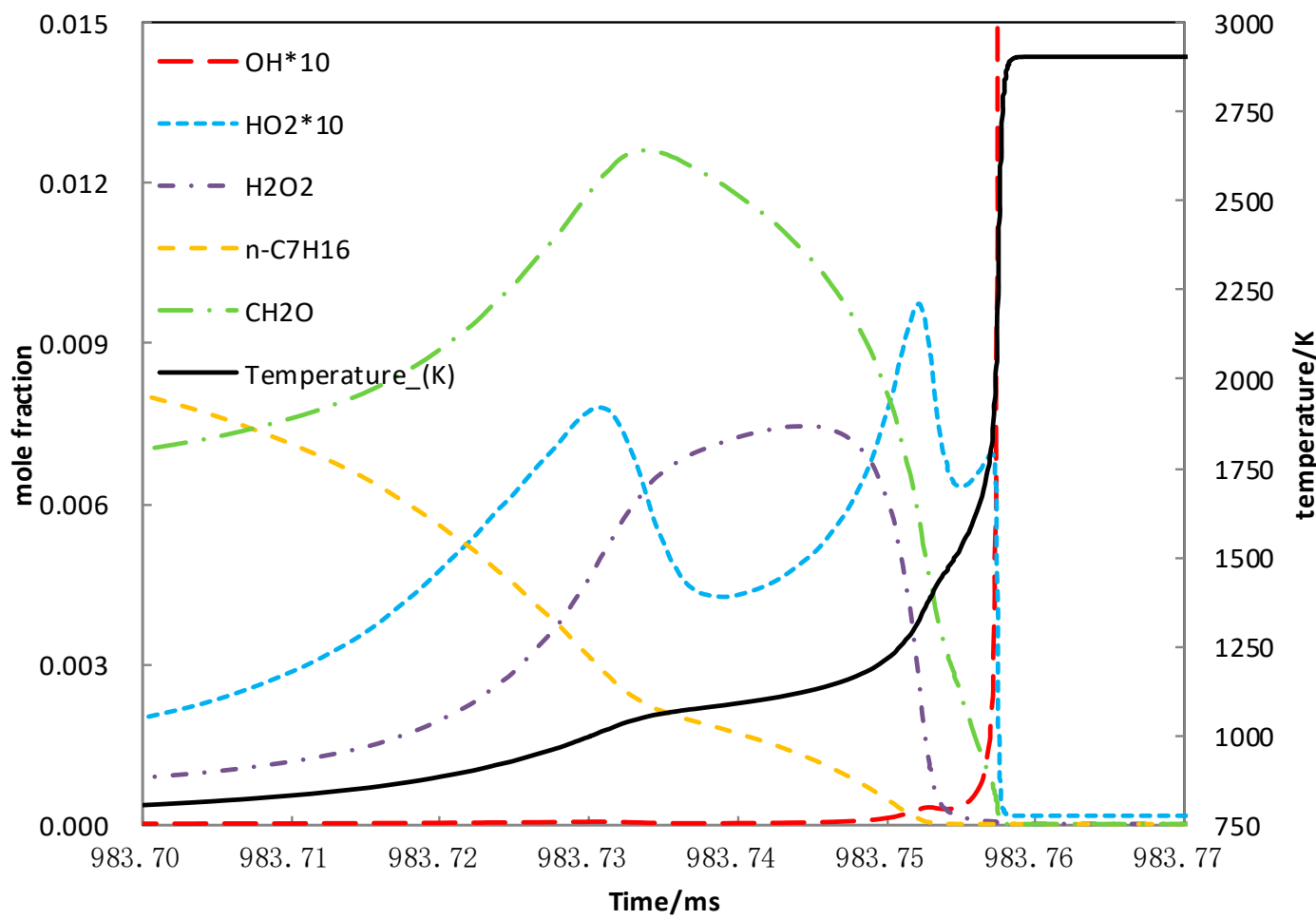

Figure 9. Mole fraction of major substances and temperature variation with time.

\subsection{Sensitivity Analysis Based on OH Group Generation and Consumption}

Hydroxyl sensitivity analysis of heptane was also carried out via CHEMKIN software. In this part, for the purpose of investigating the influence of original temperature to $-\mathrm{OH}$ (ignition delay), twenty representative reactions with great significance were studied at different original temperatures- $550 \mathrm{~K}$, $725 \mathrm{~K}, 900 \mathrm{~K}$, and $1250 \mathrm{~K}$, respectively, with simulation parameters set at a fixed equivalence ratio (its value equals 1) and an original pressure of $4000 \mathrm{kPa}$ in a homogeneous reactor.

Analyses from Figures 10-13 clearly showed that at different original temperatures, hydroxyl sensitivity between $\mathrm{n}$-heptane and methanol differed sharply. Compared with methanol, where merely 6 oxidation reactions were involved, n-heptane had more than 20 oxidation reactions. In addition, the main reaction characteristics of $n$-heptane promoting ignition at different temperatures varied greatly. In this process, a trade-off correlativity of all the new reactions might either promote or hinder the ignition. The reaction of R2233 functioned dominantly and was subsequently followed by isomerization of the peroxyheptyl group to the peroxyhydroxyalkyl group (R2234, R2228, R2227), dehydrogenation of the n-heptane and hydroxyl group (R1980, R1981), and decomposition of hydrogen peroxide ketone to form the hydroxyl group and aldehyde, a ketone small molecule (R1574, R2344, $\mathrm{R} 2349, \mathrm{R} 2350, \mathrm{R} 2355, \mathrm{R} 2359)$. At $725 \mathrm{~K}$, the most important reaction to promote ignition becomes R16, which is the decomposition reaction of hydrogen peroxide. Due to hydrogen, there is less peroxide at the early low temperature stage and, therefore, it is difficult for decomposition to proceed. When accumulation occurs at the middle temperature stage, the decomposition reaction occurs. The initial temperature is in the mid-temperature phase of $900 \mathrm{~K}$. In addition to peroxyalkyl isomerization, n-heptane, and $\mathrm{HO}_{2}$ or $\mathrm{OH}$ dehydrogenation reaction at the low temperature stage, the reaction to form hydrogen peroxide ketone and hydroxyl group is also increased (R2331, R2337, R2341) [23]. At a high temperature of $1250 \mathrm{~K}, \mathrm{R} 16$ is no longer the most important reaction to the ignition delay. After the temperature exceeds $1200 \mathrm{~K}$, the high activation energy barrier of $\mathrm{R} 1: \mathrm{H}+\mathrm{O}_{2}=\mathrm{O}+\mathrm{OH}$ is broken down, replacing $\mathrm{R} 16$ as the main source of $\mathrm{OH}$, to speed up the reaction process and undertake the decisive chain branching reaction to promote the fire [24]. 


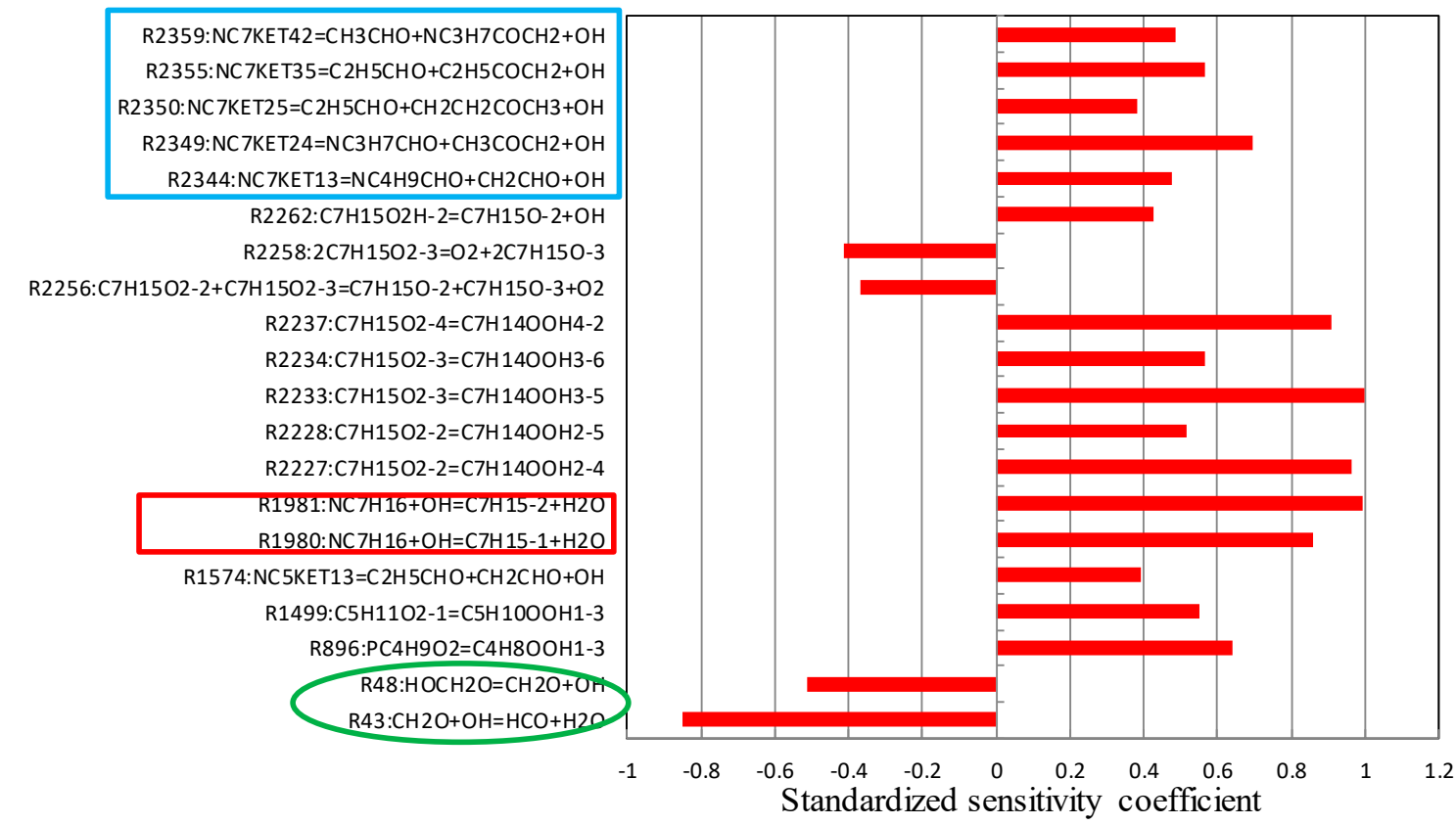

Figure 10. OH sensitivity analysis of N-heptane in the condition of $550 \mathrm{~K}$.

R2237: $\mathrm{C} 7 \mathrm{H} 15 \mathrm{O} 2-4=\mathrm{C} 7 \mathrm{H} 140 \mathrm{OH} 4-2$ R2233: $\mathrm{C} 7 \mathrm{H} 15 \mathrm{O} 2-3=\mathrm{C} 7 \mathrm{H} 140 \mathrm{OH} 3-5$ R2227: $\mathrm{C} 7 \mathrm{H} 15 \mathrm{O} 2-2=\mathrm{C} 7 \mathrm{H} 140 \mathrm{OH} 2-4$ R2222: $\mathrm{C} 7 \mathrm{H} 15 \mathrm{O} 2-1=\mathrm{C} 7 \mathrm{H} 14 \mathrm{OOH} 1-3$ R1983: $\mathrm{NC} 7 \mathrm{H} 16+\mathrm{OH}=\mathrm{C} 7 \mathrm{H} 15-4+\mathrm{H} 2 \mathrm{O}$ R1982: $\mathrm{NC} 7 \mathrm{H} 16+\mathrm{OH}=\mathrm{C} 7 \mathrm{H} 15-3+\mathrm{H} 2 \mathrm{O}$ R1981: $\mathrm{NC} 7 \mathrm{H} 16+\mathrm{OH}=\mathrm{C} 7 \mathrm{H} 15-2+\mathrm{H} 2 \mathrm{O}$ R1980: $\mathrm{NC} 7 \mathrm{H} 16+\mathrm{OH}=\mathrm{C} 7 \mathrm{H} 15-1+\mathrm{H} 2 \mathrm{O}$ $\mathrm{R} 184: \mathrm{C} 2 \mathrm{H} 5+\mathrm{O} 2=\mathrm{C} 2 \mathrm{H} 4+\mathrm{HO} 2$ $\mathrm{R} 171: \mathrm{C} 2 \mathrm{H} 5+\mathrm{HO} 2=\mathrm{C} 2 \mathrm{H} 5 \mathrm{O}+\mathrm{OH}$ $\mathrm{R} 124: \mathrm{CH} 3 \mathrm{O} 2+\mathrm{OH}=\mathrm{CH} 3 \mathrm{OH}+\mathrm{O} 2$ $\mathrm{R} 119: \mathrm{CH} 3 \mathrm{O} 2+\mathrm{HO} 2=\mathrm{CH} 3 \mathrm{O} 2 \mathrm{H}+\mathrm{O} 2$

$\mathrm{R} 109: \mathrm{CH} 3+\mathrm{HO} 2=\mathrm{CH} 3 \mathrm{O}+\mathrm{OH}$ $\mathrm{R} 47: \mathrm{CH} 2 \mathrm{O}+\mathrm{HO} 2=\mathrm{HCO}+\mathrm{H} 2 \mathrm{O} 2$ $\mathrm{R} 43 \cdot \mathrm{CH} 2 \mathrm{O}+\mathrm{OH}=\mathrm{HCO}+\mathrm{H} 2 \mathrm{O}$ $\mathrm{R} 16: \mathrm{H} 2 \mathrm{O} 2(+\mathrm{M})=2 \mathrm{OH}(+\mathrm{M})$ $\mathrm{R} 15 \cdot \mathrm{H} 2 \mathrm{O} 2+\mathrm{O} 2=2 \mathrm{HO} 2$ $\mathrm{R} 14: \mathrm{H} 2 \mathrm{O} 2+\mathrm{O} 2=2 \mathrm{HO} 2$ $\mathrm{R} 13: \mathrm{HO} 2+\mathrm{OH}=\mathrm{H} 2 \mathrm{O}+\mathrm{O} 2$ $\mathrm{R} \cdot \cdot \mathrm{H}+\mathrm{O} 2(+\mathrm{M})=\mathrm{HO} 2(+\mathrm{M})$

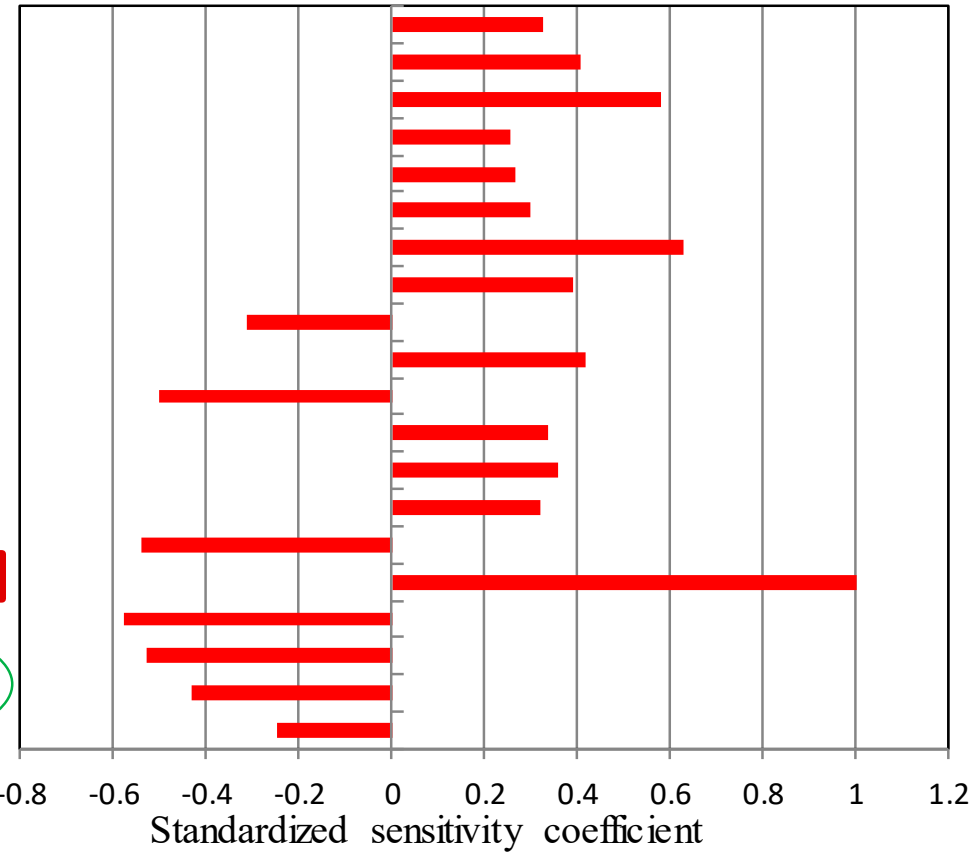

Figure 11. OH sensitivity analysis of N-heptane in the condition of $725 \mathrm{~K}$. 
R2237: $\mathrm{C} 7 \mathrm{H} 15 \mathrm{O} 2-4=\mathrm{C} 7 \mathrm{H} 14 \mathrm{OOH} 4-2$ R2233: $\mathrm{C} 7 \mathrm{H} 15 \mathrm{O} 2-3=\mathrm{C} 7 \mathrm{H} 140 \mathrm{OH} 3-5$ $\mathrm{R} 2227: \mathrm{C} 7 \mathrm{H} 15 \mathrm{O} 2-2=\mathrm{C} 7 \mathrm{H} 14 \mathrm{OOH} 2-4$ R2222: $\mathrm{C} 7 \mathrm{H} 15 \mathrm{O} 2-1=\mathrm{C} 7 \mathrm{H} 140 \mathrm{OH} 1-3$ R1983: $\mathrm{NC} 7 \mathrm{H} 16+\mathrm{OH}=\mathrm{C} 7 \mathrm{H} 15-4+\mathrm{H} 2 \mathrm{O}$ R1982: $\mathrm{NC} 7 \mathrm{H} 16+\mathrm{OH}=\mathrm{C} 7 \mathrm{H} 15-3+\mathrm{H} 2 \mathrm{O}$ R1981: $\mathrm{NC} 7 \mathrm{H} 16+\mathrm{OH}=\mathrm{C} 7 \mathrm{H} 15-2+\mathrm{H} 2 \mathrm{O}$ R1980: $\mathrm{NC} 7 \mathrm{H} 16+\mathrm{OH}=\mathrm{C} 7 \mathrm{H} 15-1+\mathrm{H} 2 \mathrm{O}$ $\mathrm{R} 184: \mathrm{C} 2 \mathrm{H} 5+\mathrm{O} 2=\mathrm{C} 2 \mathrm{H} 4+\mathrm{HO} 2$ $\mathrm{R} 171: \mathrm{C} 2 \mathrm{H} 5+\mathrm{HO} 2=\mathrm{C} 2 \mathrm{H} 5 \mathrm{O}+\mathrm{OH}$ $\mathrm{R} 124: \mathrm{CH} 3 \mathrm{O} 2+\mathrm{OH}=\mathrm{CH} 3 \mathrm{OH}+\mathrm{O} 2$ $\mathrm{R} 119: \mathrm{CH} 3 \mathrm{O} 2+\mathrm{HO} 2=\mathrm{CH} 3 \mathrm{O} 2 \mathrm{H}+\mathrm{O} 2$ $\mathrm{R} 109: \mathrm{CH} 3+\mathrm{HO} 2=\mathrm{CH} 3 \mathrm{O}+\mathrm{OH}$ $\mathrm{R} 47: \mathrm{CH} 2 \mathrm{O}+\mathrm{HO} 2=\mathrm{HCO}+\mathrm{H} 2 \mathrm{O} 2$ $\mathrm{R} 42 \cdot \mathrm{CH} 2 \mathrm{O}+\mathrm{OH}=\mathrm{HCO}+\mathrm{H} 2 \mathrm{O}$ $\mathrm{R} 16: \mathrm{H} 2 \mathrm{O} 2(+\mathrm{M})=2 \mathrm{OH}(+\mathrm{M})$ R15. $\mathrm{H} 2 \mathrm{O} 2+\mathrm{O2}=2 \mathrm{HO} 2$ $\mathrm{R} 14: \mathrm{H} 2 \mathrm{O} 2+\mathrm{O} 2=2 \mathrm{HO} 2$ $\mathrm{R} 13: \mathrm{HO} 2+\mathrm{OH}=\mathrm{H} 2 \mathrm{O}+\mathrm{O} 2$ $\mathrm{R} g \cdot \mathrm{H}+\mathrm{O} 2(+\mathrm{M})=\mathrm{HO} 2(+\mathrm{M})$

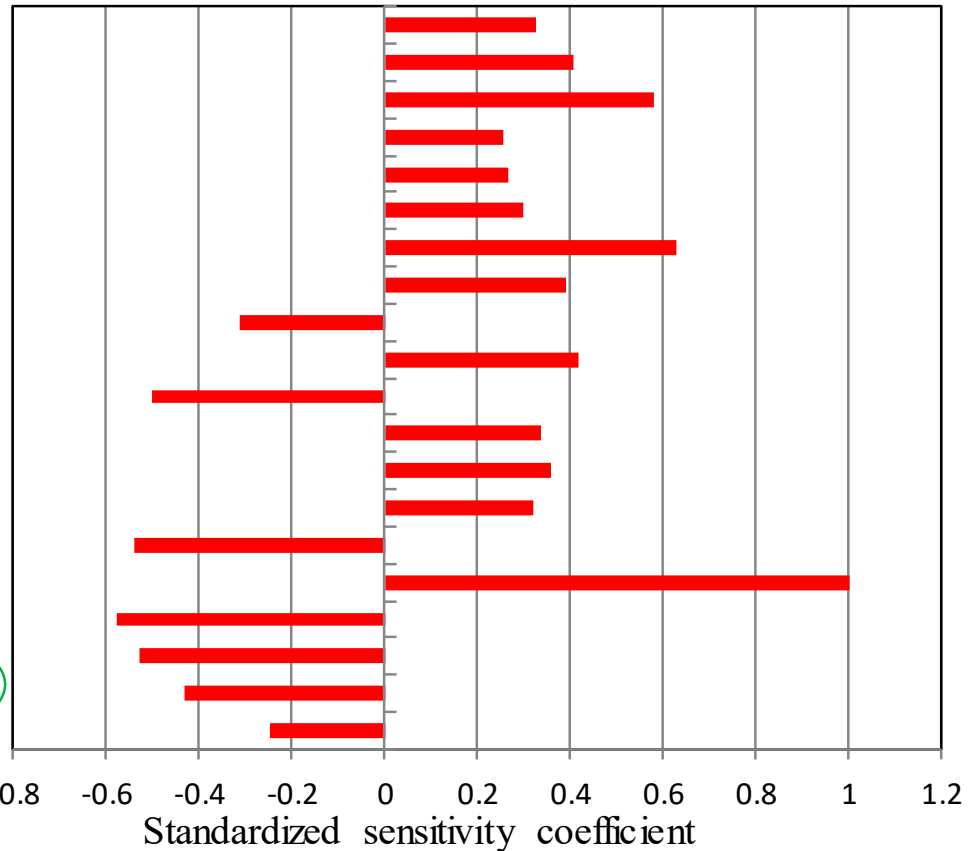

Figure 12. OH sensitivity analysis of N-heptane in the condition of $900 \mathrm{~K}$.

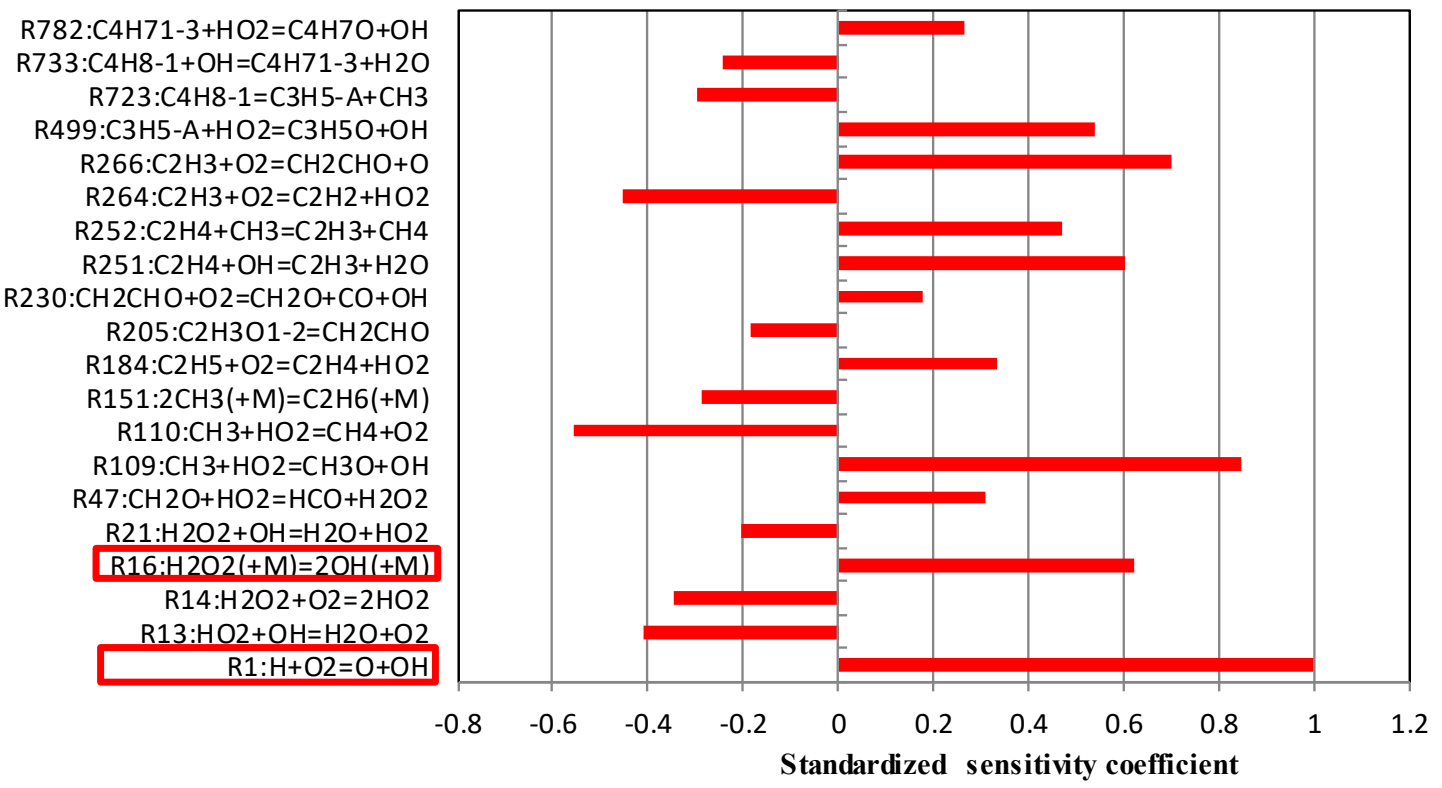

Figure 13. OH sensitivity analysis of N-heptane in the condition of $1250 \mathrm{~K}$.

Comparing the reaction schemes of n-heptane in Figures 14 and 15, it was found that the reaction path of n-heptane was very complicated. Due to the complexity of the multistage reaction, the reaction path map was relatively large and, therefore, a four-stage reaction diagram was drawn. The reaction path of n-heptane varied when the temperature was changed [25]. As a result of the complexity of the reaction path, in the circumstance where the external energy was insufficient to break the energy barrier of a reaction, the reaction proceeded toward the other reaction path, which kept the oxidation process continuing all the time. 


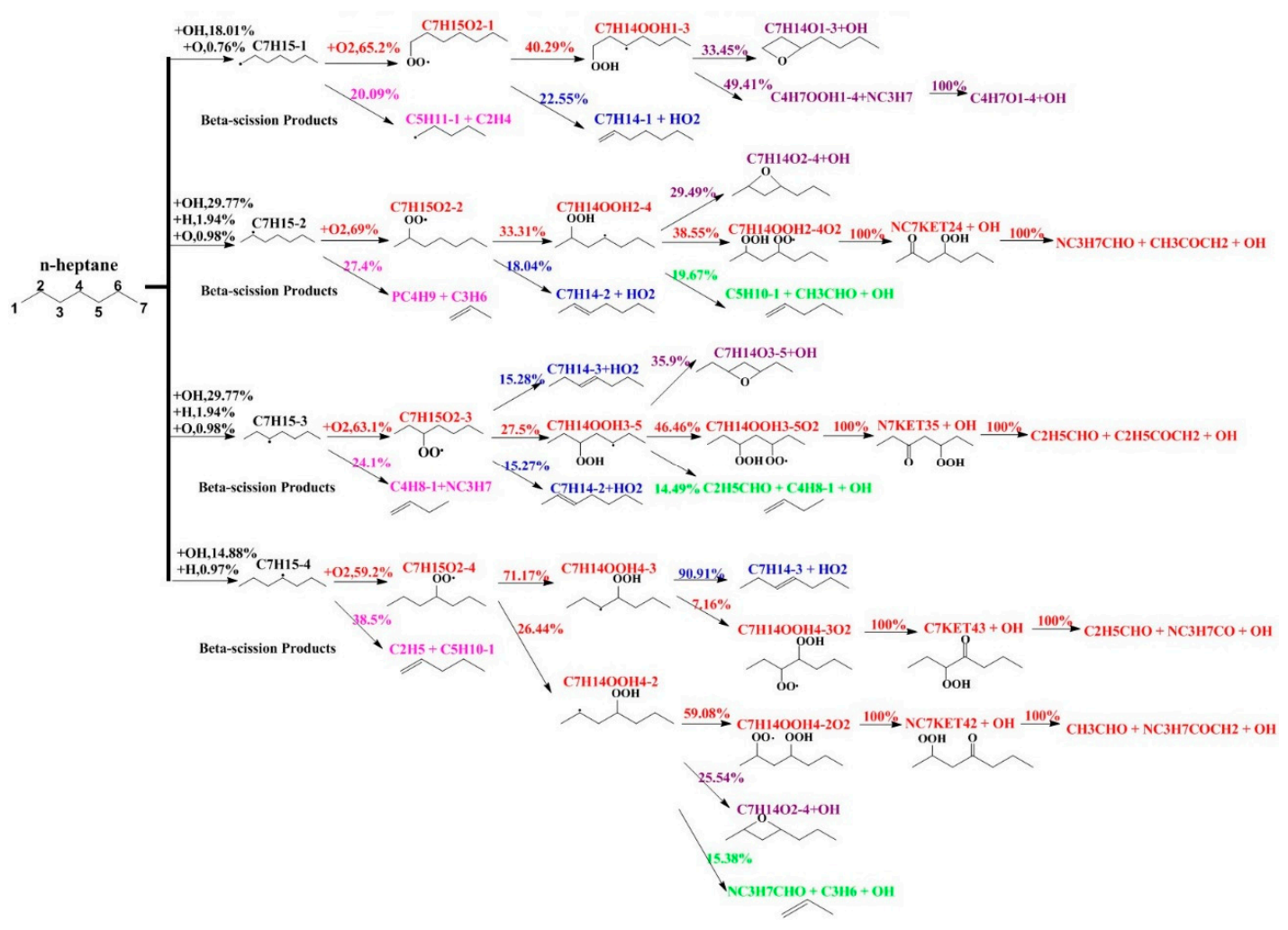

Figure 14. Heptane reaction path analysis $(900 \mathrm{~K}, 4000 \mathrm{kPa}$, equivalent ratio 1).

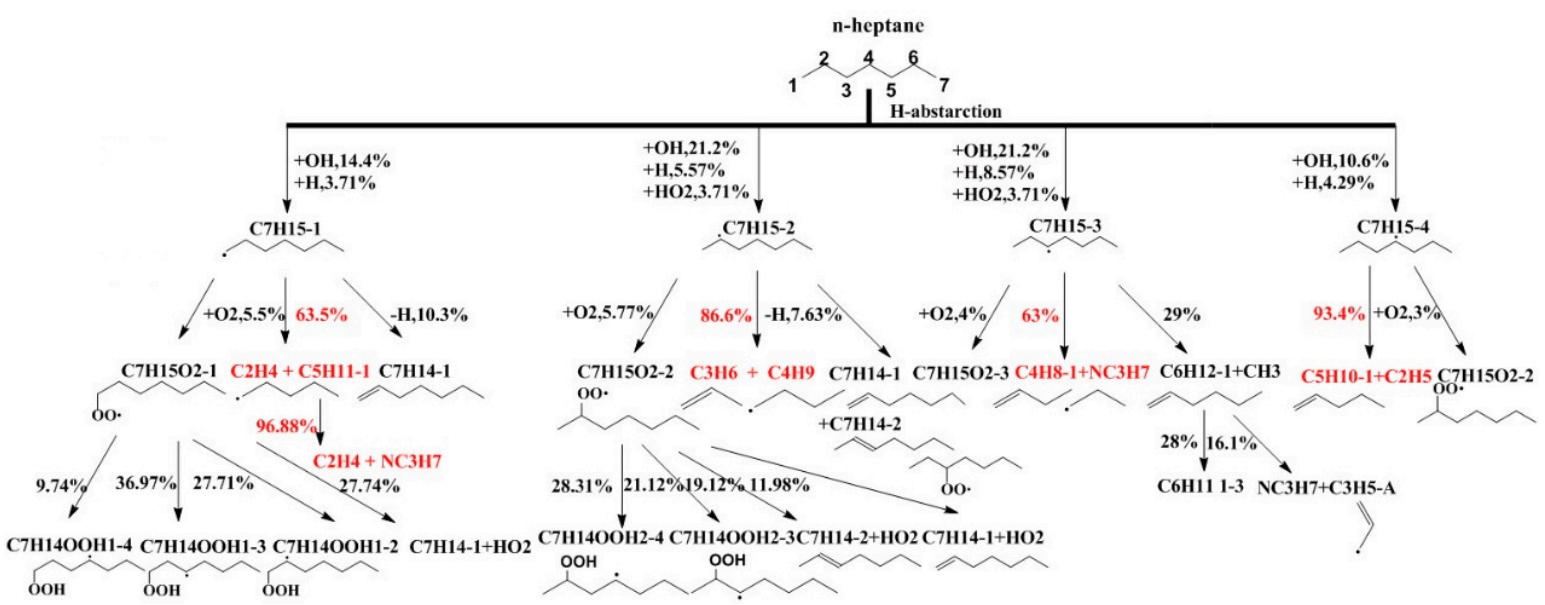

Figure 15. N-heptane reaction path analysis, temperature $1250 \mathrm{~K}$, pressure $4000 \mathrm{kPa}$, equivalent ratio 1.

\section{Conclusions}

In a large temperature range $(\varphi=0.2-2.0, \mathrm{P}=550-4000 \mathrm{kPa})$, the spontaneous ignition temperature of $\mathrm{n}$-heptane was always maintained approximately at $553 \mathrm{~K}$ and presented no significant sensitivity to the change of molar concentration of air due to the complexity of the n-heptane reaction pathways and the dominant reactions [26,27]. Five dominant reaction types, as well as multiple elementary reactions, were contained in the process of $n$-heptane oxidation, which suggested that an appropriate ignition condition was guaranteed due to the accumulation and development of active base pool from other same type elementary reactions, even in the circumstances where some certain reaction was restrained.

Whereas for the methanol counterpart, its spontaneous ignition temperature varied remarkably in the experimental conditions $(\varphi=0.2-2.0, \mathrm{P}=550-4000 \mathrm{kPa})$, a maximum temperature variation of 50 $\mathrm{K}$ proved that the spontaneous ignition temperature was extraordinarily sensitive to fuel/air molar 
concentration. Based on the sensitivity analysis of $\mathrm{OH}$ production and consumption, the conclusion would be easily drawn that the dominant reactions and active groups in the process of methanol oxidation were quite simple, with only six elementary reactions included. Therefore, when a certain chemical reaction was inhibited or the reaction conditions were not reached, the accumulation and development of the active base pool was difficult to establish, consequently making it hard to achieve the ignition condition $[15,28,29]$. In this circumstance, what was needed to ensure a steady ignition was for extra energy to be added to further improve the temperature of the inner composition.

Author Contributions: Conceptualization, Q.L., Z.L., X.R. and Y.H.; methodology, J.W.; software, J.F.; validation, Q.L., Z.L., X.R. and Y.H.; formal analysis, Z.L.; investigation, X.R. and Y.H.; data curation, Q.L.; writing-original draft preparation, Q.L., X.R. and Y.H.; writing—review and editing, Q.L., X.R. and Y.H.; project administration, Z.L.; funding acquisition, Z.L. and Y.H. All authors read and approved the manuscript.

Funding: This research was funded by the National Key Research and Development Program of China, grant number 2017YFB0306605 and 2017YFB0103503. This research was also funded by the 2018 scientific research project of the Jilin Provincial Education Department, grant number JJKH20180495KJ. This work was also supported by the program for Research Center of Automobile Safety Technology of Jilin Engineering Normal University and innovative research team of Jilin Engineering Normal University (IRTJLENU).

Acknowledgments: This work was supported by the National Key Research and Development Program of China (No. 2017YFB0306605 and No. 2017YFB0103503). This research was also supported by the 2018 scientific research project of the Jilin Provincial Education Department (JJKH20180495KJ).This work was also supported by the program for Research Center of Automobile Safety Technology of Jilin Engineering Normal University and Innovative Research Team of Jilin Engineering Normal University (IRTJLENU).

Conflicts of Interest: The authors declare no conflict of interest.

\section{References}

1. Global Emissions Management. Heavy Duty Diesel Emissions Guide: Europe, USA and Japan; Johnson Matthey Plc: London, UK, 2012.

2. Zheng, Y.N. The Critical Spontaneous Combustion Boundary Relevance Research of Single Component Fuel. Ph.D. Thesis, Ji Lin University, Changchun, China, 2017.

3. Fieweger, M.K.; Blumenthal, R.; Adomeit, G. Self-Ignition of S.I. engine model fuels: A shock tube investigation at high pressure, Combust. Flame 1997, 109, 599-619. [CrossRef]

4. Burke, U.; Metcalfe, W.K.; Burke, S.M.; Heufer, K.A.; Dagaut, P.; Curran, H.J. A detailed chemical kinetic modeling, ignition delay time and jet-stirred reactor study of methanol oxidation. Combust. Flame 2016, 165, 125-136. [CrossRef]

5. Noorani, K.E.; Akih-Kumgeh, B.; Bergthorson, J.M. Comparative high temperature shock tube ignition of $\mathrm{C}_{1}-\mathrm{C}_{4}$ primary alcohols. Energy Fuels 2010, 24, 5834-5843. [CrossRef]

6. Aranda, V.; Christensen, J.M.; Alzueta, M.U.; Glarborg, P.; Gersen, S.; Gao, Y.; Mar-shall, P. Experimental and kinetic modeling study of methanol ignition and oxidation at high pressure. Int. J. Chem. Kinet. 2013, 45, 283-294. [CrossRef]

7. Smith, J.M.; Simmie, J.M.; Curran, H.J. Autoignition of heptanes: Experiments and modeling. Int. J. Chem. Kinet. 2005, 37, 728-736. [CrossRef]

8. Xu, S.; Lin, M.C. Theoretical study on the kinetics for $\mathrm{OH}$ reactions with $\mathrm{CH}_{3} \mathrm{OH}$ and $\mathrm{C}_{2} \mathrm{H}_{5} \mathrm{OH}$. Proc. Combust. Inst. 2007, 31, 159-166. [CrossRef]

9. Lu, X.; Ji, L.; Zu, L.; Hou, Y.; Huang, C.; Huang, Z. Experimental study and chemical analysis of n-heptane homogeneous charge compression ignition combustion with port injection of reaction inhibitors. Combust. Flame 2007, 149, 261-270. [CrossRef]

10. Li, R.; Liu, Z.; Han, Y.; Tan, M.; Xu, Y.; Tian, J.; Yan, J.; Chai, J.; Liu, J.; Yu, X. Experimental and Kinetic Modeling Study of Autoignition Characteristics of $n$-Heptane/Ethanol by Constant Volume Bomb and Detail Reaction Mechanism. Energy Fuels 2017, 31, 13610-13626. [CrossRef]

11. Li, R.; Liu, Z.; Han, Y.; Tan, M.; Xu, Y.; Tian, J.; Chong, D.; Chai, J.; Liu, J.; Li, Z. Experimental and Numerical Investigation into the Effect of Fuel Type and Fuel/Air Molar Concentration on Autoignition Temperature of $n$-Heptane, Methanol, Ethanol, and Butanol. Energy Fuels 2017, 31, 2572-2584. [CrossRef] 
12. ASTM D7668-14a Standard Test Method for Determination of Derived Cetane Number (DCN) of Diesel Fuel Oils-Ignition Delay and Combustion Delay Using a Constant Volume Combustion Chamber Method; ASTM International: West Conshohocken, PA, USA, 2014.

13. Liu, J. The Characteristic and Parameter Sensitivity Analysis of Alcohol Fuel in Auto-Ignition Combustion; Jilin University: Changchun, China, 2018.

14. Chai, J. Analysis of Main Reaction Characteristics of Alkane Fuel and Its Sensitive Parameters; Jilin University: Changchun, China, 2018.

15. Hatim, M.; Simeon, C. An experimental and numerical analysis of the influence of the inlet temperature, equivalence ratio and compression ratio on the HCCI auto-ignition process of Primary Reference Fuels in an engine. Fuel Process Technol. 2008, 89, 1218-1226. [CrossRef]

16. Lv, H. Application of Chemkin Softwear in Numerical Simulation of Homogeneous Charge Compression Ignition and Fuel Modification. Ph.D. Thesis, Chang An University, Changan, China, June 2010.

17. Ilbas, M.; Crayford, A.; Yilmaz, I.; Bowen, P.; Syred, N. Laminar-burning velocities of hydrogen-air and hydrogen-methane-air mixtures: An experimental study. Int. J. Hydrogen Energy 2006, 31, 1768-1779. [CrossRef]

18. Cashdollar, K.L.; Zlochower, I.A.; Green, G.M.; Thomas, R.A.; Hertzberg, M. Flammability of methane, propane, and hydrogen gases. J. Loss Prev. Process Ind. 2000, 13, 327-340. [CrossRef]

19. Thomas, W.R.; Callahan, T.J. Homogeneous Charge Compression Ignition of Diesel Fuel; SAE Technical Paper 961160; SAE International: Warrendale, PN, USA, 1996. [CrossRef]

20. Berntsson, W.A.; Denbratt, I. HCCI Combustion Using Charge Stratification for Combustion Control; SAE Paper 2007-01-0210; SAE International: Warrendale, PN, USA, 2007. [CrossRef]

21. Korakianitis, T.; Namasivayam, A.M.; Crookes, R.J. Natu-ral gas fueled spark-ignition (SI) and compression-ignition(CI) engine performance and emissions. Prog. Energy Combust. Sci. 2011, 37, 89-112. [CrossRef]

22. Guang, H.; Zheng, Y.; Zhen, H.; Lu, X. Experimental Study of n-Heptane Ignition Delay with Carbon dioxide addition in a Rapid Compression Machine under Low Temperature Conditions. Chin. Sci. Bull. 2012, 57, 3953-3960. [CrossRef]

23. Dahnz, C.; Han, K.; Spicher, U.; Magar, M.; Schiessl, R.; Maas, U. Investigations on pre-ignition in highly supercharged SI engines. SAE Int. J. Engines 2010, 3, 214-224. [CrossRef]

24. Amann, M.; Alger, T.; Mehta, D. The effect of EGR on low-speed pre-ignition in boosted SI engines. SAE Int. J. Engines 2011, 4, 235-245. [CrossRef]

25. Khan, M.Y.; Johnson, K.C.; Durbin, T.D.; Jung, H.; Cocker, D.R., III; Bishnu, D.; Giannelli, R. Characterization of PM-PEMS for in-use measurements conducted during validation testing for the PM-PEMS measurement allowance program. Atmos. Environ. 2012, 55, 311-318. [CrossRef]

26. Onishi, S.; Jo, S.H.; Shoda, K.; Jo, P.D.; Kato, S. Active Thermo-Atmosphere Combustion (ATAC)—A new Combustion Process for Internal Combustion Engines; SAE Paper 790501; SAE International: Warrendale, PN, USA, 1979. [CrossRef]

27. Han, Y.; Li, R.; Liu, Z.; Tian, J.; Wang, X.; Kang, J. Feasibility analysis and performance characteristics investigation of spatial recuperative expander based on organic Rankine cycle for waste heat recovery. Energy Convers. Manag. 2016, 121, 335-348. [CrossRef]

28. Morteza, F.; Rahim, K.S.; Mohsen, P. EGR and Intake Charge Temperature Effects on Dual-Fuel HCCI Combustion and Emissions Characteristics; SAE Paper 2011-24-0050; Capri: Napoli, Italy, 2011. [CrossRef]

29. Liu, Q.; Liu, Z.C.; Han, Y.; Tian, J.; Wang, J.; Fang, J. Experimental Investigation of the Loading Strategy of an Automotive Diesel Engine under Transient Operation Conditions. Energies 2018, 11, 1293. [CrossRef]

(C) 2019 by the authors. Licensee MDPI, Basel, Switzerland. This article is an open access article distributed under the terms and conditions of the Creative Commons Attribution (CC BY) license (http:/ / creativecommons.org/licenses/by/4.0/). 